\title{
PENGARUH HARGA, WORD OF MOUTH DAN CITRA MEREK TERHADAP KEPUTUSAN PEMBELIAN DALAM MEMILIH EVENT ORGANIZER (STUDI KASUS DI UN PRODUCTION)
}

\author{
Nourma Wulanda \\ Program Studi Magister Manajemen, Fakultas Ekonomi, Universitas Sriwijaya \\ wulanda.nourma@yahoo.com \\ Zakaria Wahab \\ Program Studi Magister Manajemen, Fakultas Ekonomi, Universitas Sriwijaya \\ zkwahab@yahoo.com \\ Ahmad Widad \\ awidad66@yahoo.com \\ Program Studi Magister Manajemen, Fakultas Ekonomi, Universitas Sriwijaya
}

\begin{abstract}
ABSTRAK
Penelitian ini bertujuan untuk mengetahui (1) Bagaimana pengaruh harga, word of mouth dan citra merek secara simultan terhadap keputusan pembelian pada Event Organizer pada UN Production, dan Bagaimana pengaruh harga, word of mouth dan citra merek secara parsial terhadap keputusan pembelian pada Event Organizer pada UN Production.

Rancangan penelitian yang digunakan adalah asosiatif. Sampel yang digunakan sebanyak 100 responden. Untuk mengukur pengaruh antar variabel, digunakan multiple linier regression dan untuk uji hipotesis digunakan uji hipotesis F dan $\mathrm{t}$.

Hasil penelitian adalah: (1) Harga, word of mouth, dan citra merek secara simultan berpengaruh positif dan signifikan terhadap keputusan pembelian pada Even Organizer UN Production, (2) Harga berpengaruh negatif dan tidak signifikan terhadap keputusan pembelian pada Even Organizer UN Production, serta (3) Word of mouth dan citra merek secara parsial berpengaruh positif dan signifikan terhadap keputusan pembelian pada Even Organizer UN Production.
\end{abstract}

Kata Kunci:Harga, Word of Mouth, Citra Merek, Keputusan Pembelian

\begin{abstract}
This study aims to determine (1) How the impact of price, word of mouth, and branch image simultaneously to purchase decisions of Event Organizer at Un Production, and (2) How the impact of price, word of mouth, and branch image partially to purchase decisions of Event Organizer at Un Production.

The study design used is associative. The samples used were 100 respondens. To measure the influence between variables, used multiple linear regression and to test the hypothesis used to test the hypothesis $F$ and $t$.

Results of the study are: (1) Simultaneously price, word of mouth, and branch image have a significant effect to purchase decisions of Event Organizer at Un Production, (2) Price have a negative and no significant effect to purchase decisions of Event Organizer at Un Production, and (3) Partially word of mouth and branch image have a positive and significant effect to purchase decisions of Event Organizer at Un Production,
\end{abstract}

Keyword: Price, Word of Mouth, Branch Image, Purchase Decisions 
PENDAHULUAN

Event organizer merupakan sebuah lembaga yang mengelola dan mengatur suatu acara yang diselenggarakan atas permintaan klien. Ragam aktivitas event antara lain entertainment event dalam bentuk pertunjukkan musik, nonton bersama, pentas seni dan teatrikal. Di samping itu, bentuk event lain yang sering dimanfaatkan pemasar untuk mengiklankan produknya seperti sport event, exhibition, seminar atau convention event, perlombaan dan lain-lain.

Peran yang dilakukan oleh $E O$ meliputi persiapan, sosialisasi dan mengiklankan acara sampai dengan pelaksanaan acara hingga selesai. Peran lainnya yaitu mulai dari pemesanan gedung, penyediaan ruangan, persiapan interior, penyediaan sound system, penyediaan penari latar dan sebagainya. Kemudahan yang ditawarkan oleh $E O$ ini, kini berubah menjadi semacam kebutuhan. Jika sebuah lembaga, perusahaan atau perorangan menginginkan terselenggaranya sebuah acara, maka $E O$ menjadi solusi yang paling mudah.

Sejak berkembangnya event organizer di Indonesia, maka banyak kegiatan-kegiatan yang dilakukan oleh lembaga pemerintahan, swasta maupun perorangan yang menggunakan jasa event organizer. Dengan banyaknya permintaan akan jasa event organizer ini, maka semakin banyak pula bermunculan event organizer yang baru, hal ini mengakibatkan tingginya tingkat persaingan di dalam industri event organizer. Untuk dapat bersaing di dalam industri event organizer, maka jasa yang ditawarkan oleh event organizer harus dapat dikenal dan memiliki citra yang baik di mata konsumennya. Selain itu, perusahaanperusahaan even organizer harus menerapkan strategi pemasaran yang tepat, agar dapat bertahan dalam persaingan tersebut.

Perusahaan harus mampu bersaing dengan perusahaan lain yang mengeluarkan produk sejenis dan produk subsitusi, maka manajemen perusahaan harus mampu mengolah perusahaannya dengan baik, agar pelanggan yang ada tidak beralih kepada perusahaan lain. Perusahaan dituntut untuk lebih memahami segala kebutuhan dan keinginan pelanggan, sekaligus diperlukan strategi pemasaran yang baik.

Salah satu cara untuk memenangkan persaingan adalah dengan menetapkan harga 
yang bersaing, membangun word of moutn (WOM) dan meningkatkan citra merek. Menetapkan harga yang bersaing dengan jasa yang sejenis. Harga jasa merupakan salah satu faktor yang sangat menentukan dalam meningkatkan volume penjualan suatu perusahaan. Dengan harga yang sesuai dengan kemampuan konsumen dan dengan kualitas yang memadai, maka konsumen akan tertarik untuk mengkonsumsi produk tersebut.

Harga adalah sejumlah uang yang dibebankan untuk sebuah produk atau jasa, atau jumlah nilai yang konsumen pertukarkan untuk mendapatkan manfaat dari memiliki atau menggunakan produk atau jasa. Penentuan harga ini merupakan salah satu keputusan penting bagi manajemen pemasaran. Harga yang ditetapkan harus dapat menutupi semua biaya produksi dan mendapatkan laba. Tetapi harga yang ditetapkan terlalu tinggi akan berakibat kurang menguntungkan, karena jumlah pembelian akan berkurang dan mungkin semua biaya tidak dapat tertutupi dengan kerugian yang akan diderita oleh perusahaan tersebut.

Selain harga, usaha yang dapat dilakukan oleh perusahaan di dalam memenangkan persaingan adalah word of mouth. Saat ini telah ada organisasi resmi yang membahas konsep, teori, dan etika di bidang word of mouth, yaitu word of mouth marketing (WOMMA) yang menentukan standar pelaksanaan dan pengembangan program word of mouth bagi pemasar. Word of mouth sebagai usaha pemasar yang memicu konsumen untuk membicarakan, mempromosikan, merekomendasikan, dan menjual produk atau merek kepada penjual lainnya.

Word of mouth akan bersifat positif apabila konsumen telah merasa puas dan memberikan kesan positif terhadap produk (barang atau jasa) yang telah dipakainya dan akan bersifat negatif ketika konsumen tidak merasa puas dan mempunyai kesan negatif terhadap produk (barang atau jasa) yang dipakainya. Bisnis event organizer mempunyai keterkaitan erat dengan konsumennya karena keterlibatan langsung dengan para konsumennya, dengan demikian word of mouth memungkinkan terbentuknya sikap konsumen secara efektif, karena memiliki peranan penting dalam mempengaruhi konsumen lainnya.

Faktor lainnya yang dapat mempengaruhi keputusan pembelian yang 
dilakukan oleh konsumen adalah citra merek.

Citra mereka merupakan pengetahuan mengenai kita dan sikap-sikap terhadap kita yang mempunyai kelompok-kelompok yang berbeda. Citra merek merupakan hasil pandangan atau penilaian konsumen terhadap suatu merek yang baik atau buruk. Hal ini berdasarkan pertimbangan atau penyeleksian dengan membandingkan perbedaan yang terdapat pada beberapa merek, sehingga penawarannya sesuai dengan kebutuhan konsumen.

Citra merek mempunyai peran penting dalam mempengaruhi perilaku pembelian. Konsumen yang mempunyai citra positif terhadap merek cenderung memilih merek tersebut dalam pembelian. Citra merek mempresentasikan keseluruhan persepsi konsumen terhadap merek yang dibentuk karena informasi dan pengalaman konsumen terhadap suatu merek. Setiap perusahaan akan selalu berusaha untuk menjaga keunggulan citra merek, karena umumnya konsumen mengasumsikan citra merek yang baik dengan kualitas produk itu sendiri.

Penelitian tentang pengaruh harga, word of mouth, dan citra merek terhadap keputusan pembelian ini sudah dilakukan oleh banyak peneliti. Namun, masih terdapat perbedaan (gap) antara peneliti satu dengan yang lain, seperti penelitian sebelumnya yang dilakukan oleh Fredy (2017), yang mendapatkan hasil bahwa harga berpengaruh positif dan signifikan terhadap keputusan pembelian, didukung pula oleh penelitian yang dilakukan oleh Siti (2017), yang mendapatkan hasil bahwa harga berpengaruh signifikan terhadap keputusan pembelian.

Berbeda dengan hasil penelitian yang dilakukan oleh Reza (2014), yang justru mendapatkan hasil bahwa harga tidak berpengaruh signifikan terhadap keputusan pembelian, dan didukung pula oleh penelitian yang dilakukan oleh Ridwan (2015), yang mendapatkan hasil bahwa harga tidak berpengaruh signifikan terhadap keputusan pembelian.

Pada penelitian yang dilakukan oleh Ardha dan Basworo (2017), jusrtru mendapatkan hasil bahwa terdapat pengaruh yang positif dan signifikan word of mouth terhadap keputusan pembelian, didukung pula oleh penelitian yang dilakukan oleh Ardi (2017), yang mendapatkan hasil bahwa word of mouth berpengaruh signifikan terhadap Keputusan Pembelian. 
Namun berbeda dengan hasil penelitian yang dilakukan oleh I Gede dan I Made (2014), justru mendapatkan hasil bahwa word of mouth tidak berpengaruh signifikan terhadap keputusan pembelian, dan didukung pula oleh penelitian yang dilakukan oleh Leonardus, Nawazirul, dan Sendhang (2014), yang mendapatkan hasil bahwa word of mouth tidak berpengaruh signifikan terhadap keputusan pembelian.

Penelitian I Gede dan I Made (2014), mendapatkan hasil bahwa citra merek berpengaruh positif dan signifikan terhadap keputusan pembelian, didukung pula oleh penelitian yang dilakukan Leonardus, Nawazirul, dan Sendhang (2014), yang mendapatkan hasil bahwa citra merek berpengaruh positif dan signifikan terhadap keputusan pembelian, penelitian oleh Ardha dan Basworo (2017), terdapat pengaruh yang positif dan signifikan brand image terhadap keputusan pembelian, dan penelitian oleh Ardi (2017), yang mendapatkan hasil bahwa Citra Merek berpengaruh positif dan signifikan terhadap Keputusan Pembelian.

Berbeda dengan penelitian yang dilakukan oleh Reza (2014), justru mendapatkan hasil bahwa citra merek tidak berpengaruh signifikan terhadap keputusan pembelian, didukung pula dengan penelitian yang dilakukan oleh Ridwan (2015), yang mendapatkan hasil bahwa citra merek tidak berpengaruh signifikan terhadap keputusan pembelian. Penelitian oleh Fredy (2017), yang mendapatkan hasil bahwa citra merek tidak berpengaruh signifikan terhadap keputusan pembelian, dan juga hasil penelitian yang dilakukan oleh Siti (2017), yang mendapatkan hasil bahwa citra merek tidak berpengaruh signifikan terhadap keputusan pembelian.

Untuk Negeri (UN) Production merupakan salah satu perusahaan yang bergerak dalam bidang jasa event organizer di Palembang. UN Production merupakan divisi event organizer dari PT. Untuk Negeri Komunika. Jasa yang diberikan berupa penyelenggaraan dan pengelolaan yang sesuai dengan kebutuhan pihak konsumennya. Jenisjenis jasa yang ditawarkan antara lain seperti event musik (konser artis), olahraga, seminar, peluncuran produk, event advertising, gathering, pameran dan event-event lainnya.

Berdasarkan Tabel 1. dapat dijelaskan bahwa event yang diorganisir oleh UN Production, selalu mengalami penurunan dari tahun ke tahun, di mana jumlah event yang 
diorganisir pada tahun 2013 mencapai 48

event atau rata-rata 4 kegiatan dalam satu

Tabel 1. Jumlah Event yang Pernah

Dilakukan UN Production

Periode 2013 - 2017

\begin{tabular}{|c|c|c|c|c|}
\hline No. & $\begin{array}{l}\text { Tahun } \\
\text { Event }\end{array}$ & $\begin{array}{l}\text { Jenis Event } \\
\text { yang } \\
\text { Diorganisir }\end{array}$ & 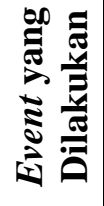 & 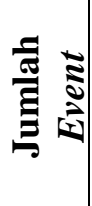 \\
\hline 1 & 2013 & $\begin{array}{l}\text { Event Organizer } \\
\text { Spesial Kontrak } \\
\text { Event Organizer } \\
\text { Spesial Program }\end{array}$ & $\begin{array}{l}12 \\
36\end{array}$ & 48 \\
\hline 2 & 2014 & $\begin{array}{l}\text { Event Organizer } \\
\text { Spesial Kontrak } \\
\text { Event Organizer } \\
\text { Spesial Program }\end{array}$ & $\begin{array}{c}8 \\
34\end{array}$ & 42 \\
\hline 3 & 2015 & $\begin{array}{l}\text { Event Organizer } \\
\text { Spesial Kontrak } \\
\text { Event Organizer } \\
\text { Spesial Program }\end{array}$ & $\begin{array}{c}7 \\
18\end{array}$ & 25 \\
\hline 4 & 2016 & $\begin{array}{l}\text { Event Organizer } \\
\text { Spesial Kontrak } \\
\text { Event Organizer } \\
\text { Spesial Program }\end{array}$ & $\begin{array}{l}10 \\
24\end{array}$ & 34 \\
\hline 5 & 2017 & $\begin{array}{l}\text { Event Organizer } \\
\text { Spesial Kontrak } \\
\text { Event Organizer } \\
\text { Spesial Program }\end{array}$ & $\begin{array}{c}5 \\
22\end{array}$ & 27 \\
\hline \multicolumn{4}{|c|}{ Jumlah } & 176 \\
\hline
\end{tabular}

Sumber: Track Record UN Production, PerJanuari 2018

bulan, dari 48 event tersebut, EO Spesial

Kontrak (melayani perusahaan atau instansi yang mengadakan event secara khusus), sebanyak 12 event dan EO Spesial Program (Showbiz, $\quad$ Expo, $\quad$ Kompetisi Olahraga/Otomotif) sebanyak 36. EO Spesial Kontrak lebih menguntungkan daripada EO Spesial Program, karena EO Spesial Kontrak sifatnya dikontrak oleh Perusahaan atau Instansi, mulai dari 1 bulan-12 bulan lamanya. Sedangkan $E O$ Spesial Program sifatnya hanya temporer saja.

Pada tahun 2014, baik EO Spesial Kontrak maupun Spesial Program mengalami penurunan yang cukup berarti. Untuk EO Spesial Kontrak, turun dari 12 event pada tahun 2012 menjadi 8 event pada tahun 2013, atau turun sebesar $33,33 \%$. Sedangkan EO Spesial Program, turun dari 36 event pada tahun 2012 menjadi 34 event pada tahun 2013, atau turun sebesar 5,56\%. Secara total, Event yang yang diorganisir pada tahun 2014, turun sebanyak 6 event $(12,5 \%)$ jika dibandingkan tahun 2014.

Pada tahun 2015, justru mengalami penurunan yang sangat drastis, secara total turun sebanyak 17 event $(40,48 \%)$ jika dibandingkan dengan tahun 2014, di mana penurunan yang terbesar adalah dari $E O$ Spesial Program, yaitu turun sebanyak 16 event (47,06\%). Pada tahun 2016, event yang diorganisir mengalami peningkatan menjadi 34 event, atau meningkat sebanyak 9 event (75,00\%), namun sayangnya pada tahun 2017 , turun kembali menjadi 27 event, atau turun sebanyak 7 event (20,59\%) jika dibandingkan 
dengan tahun 2016. Sumbangan terbesar atas

penurunan event yang diorganisir UN

Production, pada tahun 2017 ini adalah menurunnya EO Spesial Program, yaitu turun sebanyak 5 event $(50,00 \%)$ jika dibandingkan dengan tahun 2016.

Berdasarkan data internal UN Production, Event Organizer yang menjadi pesaing mereka adalah Show Biz Production,

Chacha Event Organizer, Mine Event Organizer, dan Portal Production. Dengan banyaknya perusahaan pesaing yang sejenis, maka UN Production dituntut harus menerapkan strategi pemasaran yang dapat diterapkan secara efektif, agar dapat bertahan dan memenangkan persaingan yang ada.

Berdasarkan riset gap dan penjabaran tentang fenomena UN Production di atas, maka tujuan penelitian ini adalah: (1) untuk mengetahui pengaruh harga, word of mouth dan citra merek secara simultan terhadap keputusan pembelian pada Event Organizer pada UN Production; dan (2) untuk mengetahui pengaruh harga, word of mouth dan citra merek secara parsial terhadap keputusan pembelian pada Event Organizer pada UN Production.

\section{TINJAUAN TEORI DAN}

PENGEMBANGAN HIPOTESIS

\section{Keputusan Pembelian}

Menurut Keller (2013), pada tahap keputusan pembelian konsumen akan membentuk preferensi terhadap merek-merek yang terdapat pada perangkat pilihan. Konsumen juga membentuk tujuan membeli untuk merek yang paling disukai. Menurut Schiffman dan Kanuk (2012), keputusan pembelian adalah pemilihan dari dua atau lebih alternatif pilihan keputusan pembelian. Artinya bahwa seorang konsumen bisa membuat keputusan, harus tersedia beberapa alternatif pilihan. Keputusan pembelian konsumen dipengaruhi oleh perilaku konsumen.

Menurut Walker (2013:386), faktorfaktor yang dapat mempengaruhi perilaku konsumen dalam pengambilan keputusan, adalah sebagai berikut: (a) Stimulus Pemasaran, terdiri produk, harga, distribusi, dan promosi; (b) Stimulus Lainnya, terdiri ekonomi, teknologi, politik, dan budaya; (c) Karakteristik Pembelian, terdiri dari budaya, sosial, pribadi, psikologis; (d) Proses Keputusan Pembelian, terdiri dari pengenalan masalah, pencarian informasi, dan evaluasi 
alternatif; (e) Keputusan Pembelian, terdiri dari pilihan produk, pilihan merek, pilihan pemasok, waktu pembelian, jumlah pembelian, dan cara pembayaran.

\section{Harga}

Menurut Philip (2012), harga merupakan sejumlah uang yang dibebankan untuk sebuah produk atau jasa, atau jumlah nilai yang konsumen pertukarkan untuk mendapatkan manfaat dari memiliki atau menggunakan produk atau jasa. Menurut William (2011), harga adalah suatu nilai yang dinyatakan dalam bentuk rupiah guna melakukan pertukaran/transaksi atau sejumlah uang yang harus dibayar konsumen untuk mendapatkan barang dan jasa.

Menurut Basu (2012), politik penetapan harga yang dapat digunakan oleh perusahaan yaitu:

a. Penetapan Harga Psikologis

Kebijaksanaan penetapan harga psikologis ini biasanya digunakan untuk penjualan barang pada tingkat pengecer.

b. Penetapan Harga Price Lining

Price lining ini lebih banyak digunakan oleh pengecer. Di sini penjual menentukan harga pada semua barang yang dijual. c. Potongan Harga

Potongan harga merupakan pengurangan dari harga yang ada. Biasanya potongan harga ini diwujudkan dalam bentuk tunai dan dimaksudkan untuk menarik konsumen.

d. Penetapan Harga Geografis

Pada penetapan harga ini, penjual harus mempertimbangkan ongkos angkut atau ongkos kirim untuk barang-barang yang disampaikan kepada pembeli.

\section{Word of Mouth (WOM)}

Menurut Word of Mouth Marketing Association (WOMMA) (Sumardy, 2011), menjelaskan bahwa word of mouth (WOM) merupakan usaha pemasaran yang memicu konsumen untuk membicarakan, mempromosikan, merekomendasikan, dan menjual produk/merek kita kepada pelanggan lainnya. Menurut Philip (2012), word of mouth adalah komunikasi lisan, tertulis, dan elektronik antar masyarakat yang berhubungan dengan keunggulan atau pengalaman membeli atau menggunakan produk atau jasa.

Menurut Sernovitz (2012), terdapat lima dimensi atau elemen dasar word of mouth yang dikenal dengan 5T, yaitu: 
a. Talkers (Pembicara)

Kumpulan target di mana mereka yang akan membicarakan suatu merek biasa disebut juga influencer. Talkers ini bisa siapa saja mulai dari teman, tetangga, keluarga, dan lain-lain. Selalu ada orang yang antusias untuk berbicara. Mereka ini yang paling bersemangat menceritakan pengalamannya.

\section{b. Topics (Topik)}

Topik ini berhubungan dengan apa yang ditawarkan oleh suatu merek. Seperti tawaran spesial, diskon, produk baru, atau pelayanan yang memuaskan. Topik yang baik ialah topik yang simpel, mudah dibawa, dan natural.

c. Tools (Alat)

Merupakan alat penyebaran dari topic dan talker. Topik yang telah ada juga membutuhkan suatu alat yang membantu agar topik atau pesan dapat berjalan.

\section{d. Talking Part (Partisipasi)}

Suatu pembicaraan akan hilang jika hanya ada satu orang yang berbicara mengenai suatu produk. e. Tracking (Pengawasan)

Suatu tindakan perusahaan untuk mengawasi serta memantau respon konsumen.

\section{Brand Image (Citra Merek)}

Menurut Soemirat dan Ardianto (2013), citra merek adalah pengetahuan mengenai kita dan sikap-sikap terhadap kita yang mempunyai kelompok-kelompok yang berbeda. Menurut Ruslan (2014), citra merek adalah kesan, perasaan, gambaran dari publik terhadap perusahaan. Kesan yang dengan sengaja diciptakan dari suatu objek, orang atau organisasi.

Menurut Effendy (2012), faktor-faktor pembentuk citra antara lain sebagai berikut:

a. Advertising (Periklanan)

Periklanan mempengaruhi pembentukan citra sebuah lembaga. Iklan yang ditampilkan berpengaruh dalam membangun citra.

b. Public Relation (Hubungan Masyarakat)

Public Relation turut mengambil peran dalam pembangunan citra sebuah lembaga, karena Public Relation merupakan ujung tombak sebuah lembaga dalam bermitra dan mengomunikasikan 
pesan kepada khalayak untuk membentuk citra positif.

c. Physical Image (Kesan Fisik)

Kesan fisik sebuah lembaga dapat berpengaruh terhadap pembentukan citra lembaga tersebut.

d. Word of Mouth (Komunikasi dari Mulut ke Mulut)

Komunikasi lisan merupakan salah satu alat yang digunakan oleh marketer dalam menjalankan kegiatan promosinya, selain bentuk promosi yang lainnya seperti ikan, publikasi dan sebagainya.

e. Pengalaman Nyata Konsumen dalam Memakai Barang/Jasa

Faktor ini berpengaruh dalam membentuk citra, karena dari pengalaman konsumen memakai barang/jasa akan memunculkan pandangan atau persepsi, sehingga Lembaga dapat dicitrakan seperti apa di mata konsumen.

\section{Event Organizer}

Menurut Suseno (2013), event organizer merupakan sebuah lembaga yang mengelola dan mengatur suatu acara yang diseleuggarakan atas permintaan klien. Event organizer merupakan seni mengatur dan mengelola. Ragam aktivitas event antara lain entertainment event dalam bentuk pertunjukkan musik, nonton bersama, pentas seni dan teatrikal. Di samping itu, bentuk event lain yang sering dimanfaatkan pemasar untuk mempromosikan produknya seperti sport event, exhibition, seminar atau convention event, perlombaan dan lain-lain.

Menurut Beatrix (2013), event dapat dibagi menjadi dua jenis, yaitu: (a) Pure Event (Event Murni), merupakan event yang segala sesuatunya ditanggung oleh pihak event organizer, baik kemasan, penyajian acara, maupun pencarian sponsor untuk mendapatkan dana yang nantinya dikurangi dengan seluruh biaya persiapan dan pelaksanaan event dapat menjadi keuntungan pihak event organizer; dan (b) Event by Project (Event Sponsor), merupakan event yang dikerjakan sudah berkurang sebagian, karena pembiayaan dan profit sudah diperoleh dari sponsor atau perusahaan penyelenggara. Event organizer hanya menyelesaikan tugas dengan berusaha melaksanakan event sebaikbaiknya, dengan kemasan acara yang dapat menjadi ikon produk dengan target audiens sesuai keinginan sponsor. 


\section{Kerangka Berfikir}

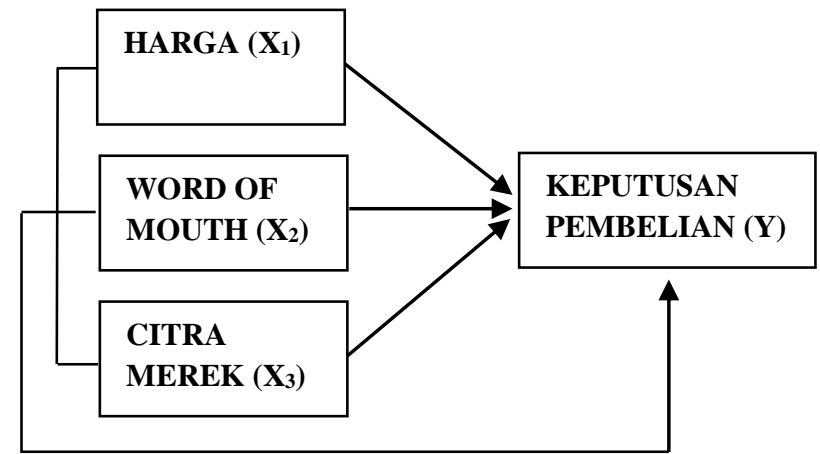

\section{Gambar 1. Kerangka Berfikir Kuantitatif} Sumber: Hasil Pemikiran Peneliti

\section{METODE RISET}

Penelitian ini akan membahas tentang 4 (empat) variabel, yang terdiri dari 3 (tiga) variabel bebas, yaitu Harga $\left(\mathrm{X}_{1}\right)$, Word of $\operatorname{Mouth}\left(\mathrm{X}_{2}\right)$, dan Citra Merek $\left(\mathrm{X}_{3}\right)$, dan 1 (satu) variabel terikat yaitu Keputusan Pembelian (Y). Objek penelitian yang akan diteliti hanyalah PT. Untuk Negeri (UN) Production. Rancangan penelitian yang digunakan dalam penelitian ini adalah asosiatif dan deskriftif kualitatif.

Teknik pengumpulan data yang digunakan adalah dokumentasi dan kuesioner. Teknik dokumentasi adalah dengan cara mengumpulkan dokumen-dokumen yang dibutuhkan pada penlitian ini, yang didapatkan langsung dari PT. Untuk Negeri (UN Production). Teknik kuesioner adalah dengan cara membagikan daftar pertanyaan kepada responden yang digunakan dalam penelitian ini, serta meminta responden untuk menjawab pertanyaan yang sudah disediakan sesuai dengan persepsi mereka masing-masing.

Populasi pada penelitian ini adalah seluruh lembaga pemerintahan, swasta, maupun perorangan yang ada di kota Palembang. Sehingga populasi dalam penelitian ini adalah infinite (tidak terbatas). Metode pengambilan sampel yang digunakan adalah teknik random sampling. Menurut Supranto (2014), jika jumlah populasi belum diketahui maka perlu diestimasi proporsi sampel dapat dihitung dengan rumus:

$$
n=\frac{1}{4}\left[\frac{Z a / 2}{E}\right]^{2}
$$

\section{Keterangan:}

$n=$ jumlah sampel yang ingin diperoleh dari jumlah populasi

$Z=$ angka yang menunjukkan penyimpangan nilai varians dari mean

$E=$ kesalahan maksimal yang mungkin dialami

$\alpha$ = tingkat kesalahan data yang dapat ditoleransi oleh peneliti

Sehingga sampel yang digunakan dalam penelitian ini, yaitu sebesar 96,04 (96) 


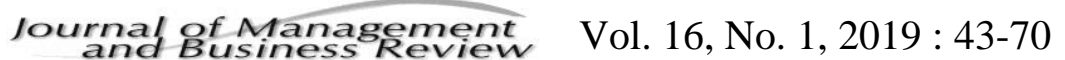

responden, penulis berinisiatif untuk

$X_{3}=$ Citra Merek

menambah sampel sebanyak 4 responden,

$e=$ Error Term

untuk berjaga-jaga jika nanti ada kuesioner yang tidak kembali, maka jumlah sampel yang diambil adalah sebanyak 100 responden.

Uji validitas instrumen yang digunakan dalam penelitian ini adalah Corrected Item-

Total Correlation. Uji reliabilitas data yang digunakan dalam penelitian ini adalah Cronbach Alpha. Uji normalitas yang digunakan adalah dengan uji KolmogorovSmirnov dan uji Normal P-P Plot. Uji multikoleniaritas dengan melihat nilai Inflation Factor (VIF) pada model regresi.

Deteksi ada tidaknya heteroskedastisitas dapat dilakukan dengan melihat ada tidaknya pola tertentu pada gambar scatterplot.

Model analisa kuantitatif yang digunakan adalah regresi linear berganda, dengan persamaan sebagai berikut:

$$
\begin{aligned}
& \boldsymbol{Y}=\boldsymbol{\alpha}+\boldsymbol{\beta}_{1 \cdot} \boldsymbol{X}_{1}+\boldsymbol{\beta}_{2 \cdot} \boldsymbol{X}_{2}+\boldsymbol{\beta}_{3} \cdot \boldsymbol{X}_{3}+\boldsymbol{e} \\
& \text { Keterangan: } \\
& Y=\text { Keputusan Pembelian } \\
& \alpha=\text { Nilai konstanta } \\
& \beta_{1}, \beta_{2}, \beta_{3},=\text { Koefisien regresi } \\
& X_{1}=\text { Harga } \\
& X_{2}=\text { Word of Mouth }
\end{aligned}
$$

\section{HASIL PENELITIAN DAN \\ PEMBAHASAN}

Data yang digunakan sudah dinyatakan valid dan reliabel. Data-data yang digunakan dalam penelitian ini terdistribusi dengan normal, tidak terjadi multikolinieritas, dan tidak terjadi heterokedastisitas, sehingga layak untuk dianalisis dengan regresi linier berganda.

Berdasarkan pengujian distribusi frekuensi data dengan menggunakan bantuan program SPSS, diperoleh hasil distribuasi frekuensi hasil jawaban responden pada variabel-variabel yang digunakan, adalah sebagaimana tertera dalam tabel 2 .

Item Y.5., mendapatkan nilai rata-rata terbesar yaitu 4,46 (sangat baik), berarti secara umum responden mencari informasi tentang jasa Event Organizer UN Production dari rekan kerja. Item Y.10., mendapatkan nilai rata-rata terkecil yaitu 3,60 yang masuk dalam kategori baik, berarti secara umum responden membandingkan harga jasa Event Organizer yang satu dengan yang lainnya. 
Tabel 2. Distribusi Frekuensi Hasil Jawaban Kuesioner Variabel Keputusan Pembelian (Y) (Item Y.9; Y.11; \& Y.12 Tidak Valid)

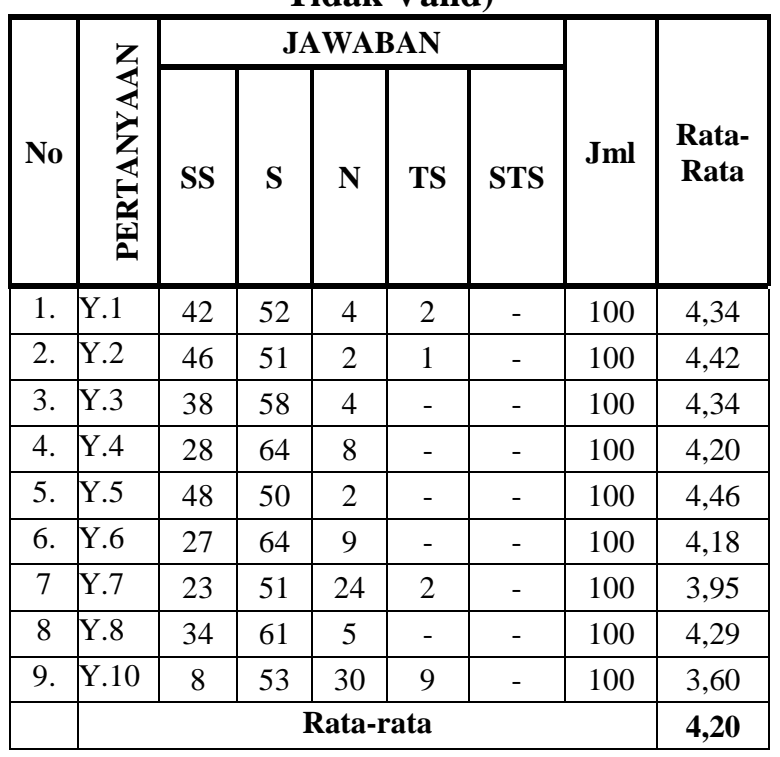

Sumber: Hasil Olahan Data

Pada tabel 3, diketahui bahwa item $\mathrm{X}_{1} .8$ mendapatkan nilai rata-rata terbesar yaitu 4,21 yang masuk dalam kategori sangat baik. Berarti secara umum responden menganggap bahwa Event Organizer UN Production menetapkan biaya transportasi ditanggung oleh UN Production. Item $\mathrm{X}_{1} .10$ mendapatkan nilai rata-rata terkecil, yaitu 3,71 yang masuk dalam kategori baik. Berarti secara umum responden menganggap bahwa Event Organizer UN Production memberikan potongan secara tunai kepada pelangganpelanggannya.
Tabel 3. Distribusi Frekuensi Hasil Jawaban Kuesioner pada Variabel Harga $\left(X_{1}\right)$ (Item $X_{1.1}$ dan $X_{1.4}$ Tidak Valid)

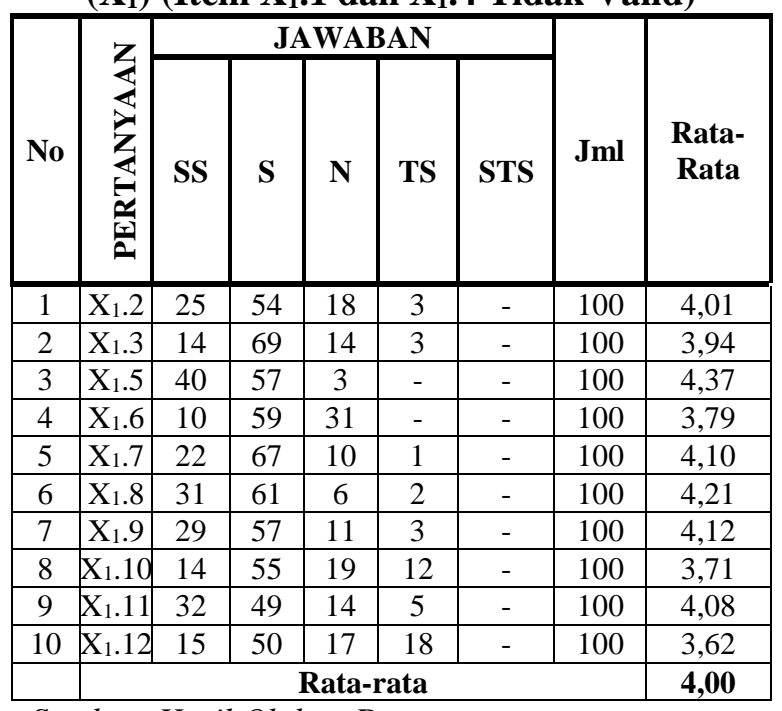

Sumber: Hasil Olahan Data

Tabel 4. Distribusi Frekuensi Hasil Jawaban Kuesioner pada Variabel Word of Mouth $\left(\mathrm{X}_{2}\right)\left(\right.$ Item $\mathrm{X}_{2.8}, \mathrm{X}_{2.9}$ dan $\mathrm{X}_{2.12}$ Tidak Valid)

\begin{tabular}{|c|c|c|c|c|c|c|c|c|}
\hline \multirow[b]{2}{*}{ No } & \multirow{2}{*}{ 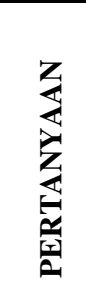 } & \multicolumn{5}{|c|}{ JAWABAN } & \multirow[b]{2}{*}{ Jml } & \multirow[b]{2}{*}{$\begin{array}{c}\text { Rata- } \\
\text { Rata }\end{array}$} \\
\hline & & SS & $\mathbf{S}$ & $\mathbf{N}$ & TS & STS & & \\
\hline 1 & $\mathrm{X}_{2.1}$ & 12 & 74 & 14 & - & - & 100 & 3,98 \\
\hline 2 & $\mathrm{X}_{2.2}$ & 16 & 77 & 7 & - & - & 100 & 4,09 \\
\hline 3 & $\mathrm{X}_{2.3}$ & 13 & 75 & 12 & - & - & 100 & 4,01 \\
\hline 4 & $\mathrm{X}_{2.4}$ & 28 & 54 & 18 & - & - & 100 & 4,10 \\
\hline 5 & $X_{2.5}$ & 18 & 64 & 18 & - & - & 100 & 4,00 \\
\hline 6 & $\mathrm{X}_{2.6}$ & 33 & 57 & 9 & 1 & - & 100 & 4,22 \\
\hline 7 & $\mathrm{X}_{2.7}$ & 32 & 49 & 18 & 1 & - & 100 & 4,12 \\
\hline 8 & $\mathrm{X}_{2.10}$ & 13 & 44 & 18 & 25 & - & 100 & 3,45 \\
\hline 9 & $\mathrm{X} 2.11$ & 22 & 62 & 16 & - & - & 100 & 4,06 \\
\hline & \multicolumn{7}{|c|}{ Rata-rata } & 4,00 \\
\hline
\end{tabular}

Sumber: Hasil Olahan Data

Pada tabel 4, diketahui bahwa item $\mathrm{X}_{2} .6$ mendapatkan nilai rata-rata terbesar yaitu 4,22 yang masuk dalam kategori sangat baik. Artinya, secara umum responden menganggap bahwa UN Production merancang Event Organizer mengikuti perkembangan zaman. 
Item $\mathrm{X}_{2} .10$ mendapatkan nilai rata-rata terkecil yaitu 3,45 yang masuk dalam kategori baik. Artinya, secara umum responden menganggap bahwa UN Production menempatkan tenaga penjual yang memiliki pengetahuan luas tentang jasa Event Organizer yang ditawarkannya.

Item $\mathrm{X}_{3.4 .}$., mendapatkan nilai rata-rata terbesar yaitu 4,28 yang masuk dalam kategori sangat baik, berarti secara umum responden menganggap bahwa Event Organizer UN Production mengembangkan hubungan masyarakat yang baik pada pelangganpelanggannya. Item $\mathrm{X}_{3} .6$., mendapatkan nilai rata-rata terkecil, yaitu 3,73 yang masuk dalam kategori baik, berarti secara umum responden menganggap bahwa Event Organizer UN Production membangun komunitas untuk mengakraban diri dengan pelangganpelanggannya.

\section{Analisis Regresi Linier Berganda}

Berdasarkan hasil pengujian regresi dengan menggunakan bantuan program SPSS diperoleh hasil uji regresi linier berganda, yaitu sebagaimana tertera dalam tabel 6 .
Tabel 5. Distribusi Frekuensi Hasil Jawaban Kuesioner pada Variabel Citra Merek $\left(X_{3}\right)\left(I t e m X_{3} .1, X_{3.8}, X_{3.12}\right.$, dan $\mathrm{X}_{3.15}$ Tidak Valid)

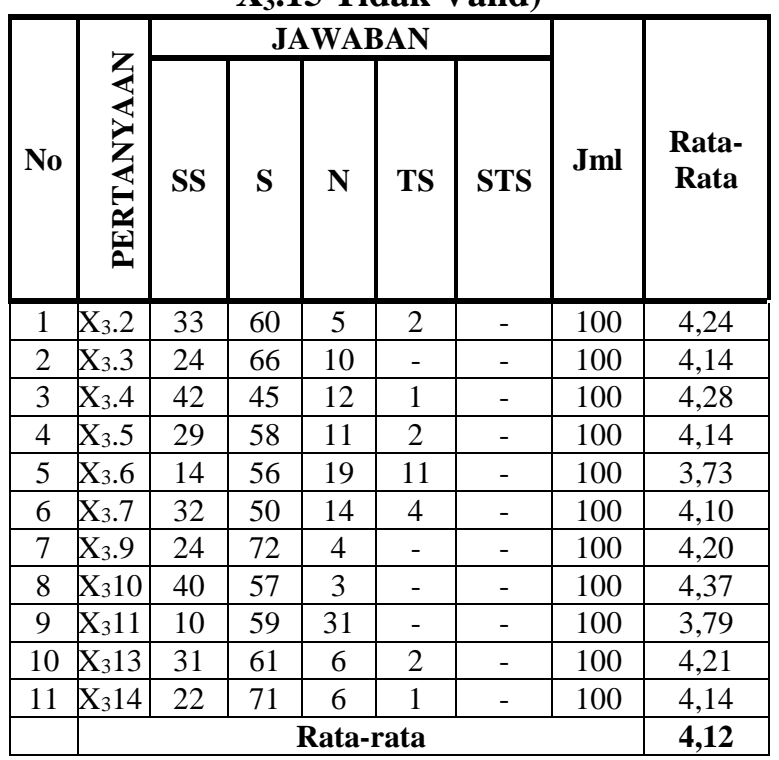

Sumber: Hasil Olahan Data

Tabel 6. Hasil Pengujian

Regresi Linier Berganda

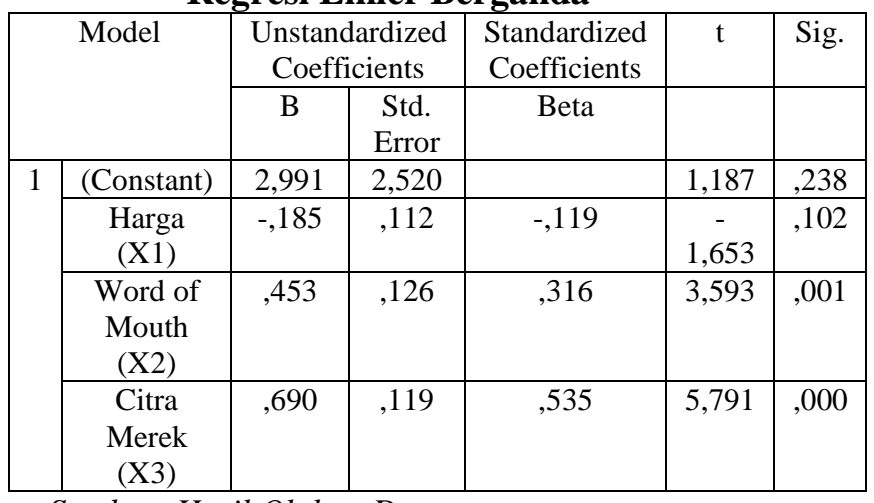

Sumber: Hasil Olahan Data

Sehingga dapat dibentuk suatu persamaan regresi linier berganda, yaitu sebagai berikut:

$$
\begin{aligned}
Y= & \alpha+\beta_{1 .} X_{1}+\beta_{2} \cdot X_{2}+\beta_{3} . X_{3}+e \\
Y= & 2,991-0,185 . X_{1}+0,453 . X_{2}+ \\
& 0,690 . X_{3}
\end{aligned}
$$

Berdasarkan persamaan di atas, maka dapat diinterpretasikan pengaruh masing- 
masing variabel bebas terhadap variabel terikat, yaitu sebagai berikut:

a. Nilai koefisen regresi variabel Harga $\left(X_{1}\right)$ sebesar $-0,185$. Hal ini berarti bahwa variabel Harga $\left(\mathrm{X}_{1}\right)$ mempengaruhi variabel Keputusan Pembelian (Y) sebesar $-0,185(-18,5 \%)$ (berbanding terbalik).

b. Nilai koefisen regresi variabel Word of Mouth $\left(\mathrm{X}_{2}\right)$ sebesar 0,453 . Hal ini berarti bahwa variabel Word of Mouth $\left(\mathrm{X}_{2}\right)$ mempengaruhi variabel Keputusan Pembelian (Y) sebesar $0,453 \quad(45,3 \%)$ (berbanding lurus).

c. Nilai koefisen regresi variabel Citra Merek $\left(\mathrm{X}_{3}\right)$ sebesar 0,690. Hal ini berarti bahwa variabel Citra Merek $\left(\mathrm{X}_{3}\right)$ mempengaruhi variabel Keputusan Pembelian (Y) sebesar $0,690(69,0 \%)$ (berbanding lurus).

\section{Hasil Uji Koefisien Determinasi}

Berdasarkan hasil pengujian $R$-Square dengan menggunakan bantuan program SPSS, diperoleh hasil uji koefisien determinasi, adalah sebagai berikut:
Tabel 7. Hasil Uji Koefisien Determinan

\begin{tabular}{|c|c|c|c|c|c|}
\hline$\frac{\bar{d}}{0}$ & $\mathrm{R}$ & $\begin{array}{c}\mathrm{R} \\
\text { Square }\end{array}$ & 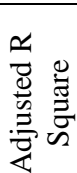 & $\begin{array}{c}\text { Std } \\
\text { Error of } \\
\text { the } \\
\text { Estimate }\end{array}$ & 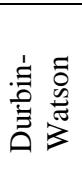 \\
\hline 1 &, $749^{a}$ & ,562 &, 548 & $\begin{array}{c}3,09368 \\
4\end{array}$ & 2,064 \\
\hline
\end{tabular}

Sumber: Hasil Olahan Data

Nilai $R$-Square sebesar $0,562(56,2 \%)$, maka dapat disimpulkan bahwa Keputusan Pembelian dapat dijelaskan oleh Harga, Word of Mouth dan Citra Merek sebesar 56,2\%; sedangkan sisanya sebesar $43,8 \%$ dijelaskan oleh faktor-faktor lain yang tidak masuk ke dalam penelitian ini, seperti kualitas jasa, pelayanan, periklanan, promosi penjualan, publisitas, dan faktor-faktor lainnya.

\section{Hasil Pengujian Hipotesis F (Anova)}

Berdasarkan pengujian dengan bantuan program SPSS, maka diperoleh Hasil Pengujai Hipotesis F (Anova), yaitu sebagaimana tertera pada tabel 8 .

Nilai F-tabel $(5 \% ; 96 ; 3)$ adalah sebesar 2,700, sehingga nilai F-hitung $(41,015)>$ Ftabel $(2,700)$ atau Sig F $(0,000)<\alpha(0,05)$, maka $\mathrm{H}_{0}$ ditolak dan $\mathrm{Ha}$ diterima, berarti Harga, Word of Mouth, dan Citra Merek secara simultan berpengaruh positif dan signifikan terhadap Keputusan Pembelian pada Even Organizer UN Production. 
Tabel 8. Hasil Uji Hipotesis F (Anova)

\begin{tabular}{|c|c|c|c|c|c|c|}
\hline \multicolumn{2}{|r|}{ Model } & $\begin{array}{l}\text { Sum of } \\
\text { Squares }\end{array}$ & $\mathrm{df}$ & $\begin{array}{c}\text { Mean } \\
\text { Square }\end{array}$ & $\mathrm{F}$ & Sig. \\
\hline 1 & $\begin{array}{c}\text { Regressio } \\
n\end{array}$ & $\begin{array}{c}1177,64 \\
7\end{array}$ & 3 & $\begin{array}{c}392,54 \\
9\end{array}$ & $\begin{array}{c}41,01 \\
5\end{array}$ & $\begin{array}{c}, 000 \\
\text { a }\end{array}$ \\
\hline & Residual & 918,805 & $\begin{array}{l}9 \\
6 \\
\end{array}$ & 9,571 & & \\
\hline & Total & $\begin{array}{c}2096,45 \\
2\end{array}$ & $\begin{array}{l}9 \\
9\end{array}$ & & & \\
\hline
\end{tabular}

Sumber: Hasil Olahan Data (Lampiran 9)

\section{Hasil Pengujian Hipotesis t (Uji Parsial)}

Nilai t-tabel $(5 \% ; 98)$ sebesar 1,985 .

Berdasarkan Tabel 6 (Hasil Pengujian Regresi

Linier Berganda), nilai t-hitung variabel Harga

$\left(\mathrm{X}_{1}\right)$ sebesar $-1,653$; berarti t-hitung $(-1,653)$

$<$ t-tabel $(-1,985)$; sehingga Ho diterima dan

Ha ditolak, berarti Harga berpengaruh negatif dan tidak signifikan terhadap Keputusan Pembelian pada Even Organizer UN Production.

Nilai t-hitung variabel Word of Mouth $\left(\mathrm{X}_{2}\right)$ adalah sebesar 3,593; berarti t-hitung $(3,593)>$ t-tabel $(1,985)$; maka Ho ditolak dan Ha diterima, artinya Word of Mouth berpengaruh positif dan signifikan terhadap Keputusan Pembelian pada Even Organizer UN Production.

Nilai t-hitung variabel Citra Merek $\left(\mathrm{X}_{3}\right)$ adalah sebesar 5,791 dan signifikansi (Sig t) sebesar 0,000; berarti t-hitung $(5,791)>t$-tabel $(1,985)$ atau Sig t $(0,000)<\alpha(0,05)$; maka Ho ditolak dan Ha diterima, artinya Citra Merek berpengaruh positif dan signifikan terhadap
Keputusan Pembelian pada Even Organizer UN Production.

\section{Pembahasan}

Berdasarkan hasil pengujian dengan analisis regresi berganda dan uji hipotesis t, dapat dijelaskan bahwa variabel harga memberikan dampak negatif terhadap keputusan pembelian yang dilakukan oleh konsumen. Maksudnya bahwa jika harga barang atau jasa ditawarkan meningkat, maka akan dapat menurunkan minat konsumen untuk membeli barang atau jasa tersebut, sebaliknya jika harga barang atau jasa yang ditawarkan turun (rendah), maka akan dapat meningkatkan minat konsumen untuk membeli barang atau jasa tersebut.

Hasil penelitian ini sejalan dengan teori yang diungkapkan oleh Walker (2013), bahwa harga dapat memberikan dampak menurunnya keputusan konsumen untuk membeli barang atau jasa yang dibutuhkannya. Dikarenakan semakin tinggi harga, maka daya beli konsumen akan semakin menurun, sehingga menurunkan keputusan konsumen untuk barang atau jasa yang dibutuhkannya. Sejalan juga dengan teroi yang diungkapkan oleh Sumarwan (2012), bagi konsumen, harga merupakan faktor yang sensitif. Jika harga 
yang ditawarkan oleh penjual terlalu tinggi, maka akan mengurangi daya beli konsumen, sehingga dapat mengurangi permintaan akan barang yang ditawarkan, karena konsumen cenderung membeli barang dengan mengharapkan harga yang serendah mungkin.

Hasil penelitian ini sejalan dengan hasil penelitian yang dilakukan oleh Reza (2014), yang mendapatkan hasil bahwa harga tidak berpengaruh signifikan terhadap keputusan pembelian, dan didukung pula oleh penelitian yang dilakukan oleh Ridwan (2015), yang mendapatkan hasil bahwa harga tidak berpengaruh signifikan terhadap keputusan pembelian.

Harga menjadi sesuatu yang cukup sensitif bagi konsumen. Salah satu pertimbangan konsumen di dalam mengambil keputusan untuk membeli suatu produk adalah harga. Kecenderungan konsumen akan memilih harga yang murah (ekonomis), tetapi dengan kualitas produk yang baik. Oleh karena itu, dalam merancang strategi pemasaran perusahaan harus benar-benar memperhatikan masalah harga ini. Hasil penelitian ini menegaskan kembali bahwa keputusan konsumen di dalam membeli barang atau jasa, akan sangat dipengaruhi oleh harga barang atau jasa yang ditawarkan. Jika harga yang ditawarkan terlalu tinggi, maka akan mengakibatkan menurunnya keputusan konsumen di dalam membeli barang atau jasa yang ditawarkan. Sebaliknya jika harga yang ditawarkan rendah atau bersaing, maka keputusan konsumen di dalam membeli barang atau jasa akan meningkat. Dengan kata lain bahwa harga akan berbanding terbalik dengan keputusan konsumen.

Begitu pula dengan jasa Event Organizer yang ditawarkan oleh UN Production. Tentu saja ada harga yang harus dibayar oleh konsumen. Harga yang dimaksud dalam hal ini adalah biaya yang harus dikeluarkan oleh konsumen dalam memanfaatkan jasa Event Organizer. Jika harga yang dibebankan terlalu tinggi, tentulah akan mengakibatkan konsumen mengurangi keputusannya untuk menggunakan jasa Event Organizer UN Production, dan bukan tidak mungkin konsumen akan berpindah ke Event Organizer yang juga menawarkan jasa yang sama. Sementara itu, jika harga yang ditetapkan terlalu rendah, maka hal tersebut dapat meningkatkan keputusan konsumen untuk menggunakan jasa Event Organizer UN Production. Namun di sisi lain, UN 
Production akan mengalami kerugian karena menetapkan harga yang terlalu rendah.

Jadi menurut peneliti, UN Production harus memperhatikan penetapan harga jasa Event Organizer yang ditawarkannya. Jika terlalu tinggi, maka akan dapat mengurangi keputusan konsumen di dalam menggunakan jasa Event Organizer, sedangkan jika terlalu rendah maka dapat merugikan UN Production. Namun bukan tidak mungkin dilakukan, jika UN Production memiliki keunggulan bersaing pada biaya produksi yang rendah (low cost). Jika UN Production dapat menekan biaya produksi, maka bukan tidak mungkin UN Production dapat menekan harga jualnya. Namun hal tersebut bukanlah sesuatu yang mudah untuk dilakukan oleh UN Production. Jadi seharusnya UN Production menetapkan harga yang bersaing, yaitu tidak terlalu tinggi dan juga tidak terlalu rendah, sehingga diharapkan konsumen akan tetap membeli jasa Event Organizer yang ditawarkan UN Production, dan sekaligus tidak merugikan UN Production.

Dalam menetapkan harga, UN Production dapat melihat dari sisi: Pertama, kualitas jasa yang ditawarkan, maksudnya jika kualitas jasa Event Organizer yang ditawarkan tinggi, maka bisa saja UN Production menetapkan harga yang sedikit lebih mahal. Kedua; biaya jasa disesuaikan dengan kemampuan konsumen. Maksudnya dalam menetapkan harga, UN Production juga harus melihat dari kemampuan konsumennya. Misalnya pada jasa Event Organizer tertentu seperti untuk event reunian, pernikahan, ulang tahun, atau yang lainnya, alangkah baiknya UN Production menetapkan harga sesuai dengan kemampuan konsumen. Namun jika berkaitan dengan event launching product, sport event, exhibition, seminar atau convention event, perlombaan dan lain-lain, UN Production dapat menetapkan harga yang cukup tinggi. Ketiga, memberikan potongan harga, misalnya dalam jasa Event Organizer, jika konsumen mengadakan event yang cukup besar dan dengan waktu yang cukup lama, maka UN Production dapat memberikan potongan harga.

Berdasarkan hasil pengujian dengan menggunakan analisis regresi linier berganda dan uji hipotesis t, dapat dijelaskan bahwa variabel Word of Mouth $\left(\mathrm{X}_{2}\right)$ memberikan dampak yang cukup besar dan signifikan terhadap keputusan pembelian jasa Even Organizer pada UN Production yang 
dilakukan konsumen. Hal ini menjelaskan bahwa pembicaraan yang dilakukan oleh pelanggan kepada calon konsumen (word of mouth), cukup efektif dalam mempengaruhi keputusan pembelian yang dilakukan oleh konsumen.

Komunikasi dari mulut ke mulut (word of mouth) memang mempunyai pengaruh yang sangat besar kepada konsumen, karena informasi yang didapat dianggap nyata dan jujur dan orang yang mendengarkan cenderung lebih mempercayai informasi barang atau jasa yang mereka dengar dari teman, kerabat atau orang terdekat yang berpengalaman terhadap barang atau jasa yang dimaksud, dibandingkan dengan informasi dari iklan.

Word of mouth akan terjadi secara alami ketika konsumen menjadi pendukung suatu merek atau produk karena merasa puas dengan barang atau jasa yang dipakai atau dikonsumsinya. Umumnya konsumen antusias untuk mengajak orang lain memilih merek atau produk yang telah dipakainya atau bisa disebut sebagai organic word of mouth. Selain ajakan dari konsumen, jika perusahaan melakukan sebuah kampanye yang dibuat untuk mendorong atau mempercepat word of mouth pada suatu komunitas yang ada, juga dapat menciptakan persepsi positif bagi orang lain terhadap barang atau jasa yang ditawarkan.

Ketika calon konsumen sudah mengetahui tentang produk yang telah ditawarkan melalui promosi maupun mendapatkan informasi dari mulut ke mulut, maka calon konsumen berhak melakukan pertimbangan sebelum mereka memutuskan sebuah keputusan dalam pembelian. Nanti setelah konsumen sudah menggunakan barang atau jasa, barulah konsumen akan melakukan penilaian terhadap barang atau jasa yang telah dikonsumsinya, apabila barang atau jasa tersebut memberikan kepuasan dan kesan positif kepada konsumen, maka word of mouth positif yang kemungkinan akan terjadi. Begitu pula sebaliknya apabila konsumen kecewa terhadap barang atau jasa yang digunakannya, berarti muncul kesan negatif dalam diri konsumen, maka word of mouth negatif yang kemungkinan akan terjadi.

Word of mouth merupakan akibat dari kepuasan atau ketidak puasan dan kesan konsumen terhadap barang atau jasa yang telah dikonsumsinya. Word of mouth akan bersifat positif apabila konsumen telah merasa puas dan memberikan kesan positif terhadap 
barang atau jasa yang telah dipakainya dan akan bersifat negatif ketika konsumen tidak merasa puas (kecewa) dan mempunyai kesan negatif terhadap barang atau jasa yang dipakainya.

Seperti yang telah diketahui, berbagai macam Event Organizer yang telah berdiri mempunyai keunggulan dan keunikan masingmasing yang menjadi suatu kekuatan tersendiri bagi Event Organizer untuk tetap mempertahankan konsumennya, sekaligus menarik minat konsumen yang baru maupun untuk tetap bersaing dengan pesaing yang lain ataupun pesaing yang baru berdiri. Event Organizer mempunyai keterkaitan erat dengan konsumennya karena keterlibatan langsung dengan para konsumennya, dengan demikian word of mouth memungkinkan terbentuknya sikap konsumen secara efektif, karena memiliki peranan penting dalam mempengaruhi konsumen lainnya.

Oleh karena itu sebaiknya Event Organizer yang ditawarkan UN Production yang mempunyai keunikan akan menciptakan sebuah pemikiran konsumen untuk diceritakan kepada calon konsumen baru, sehingga Event Organizer tidak terlalu mementingkan promosi yang lain, tetapi lebih fokus kepada bagaimana memberikan pelayanan yang baik kepada konsumen dan juga keunggulan serta keunikan jasa yang ditawarkan, supaya dapat tercipta sebuah word of mouth yang efektif.

Berdasarkan hasil pengujian dengan analisis regresi berganda dan uji hipotesis t, dapat dijelaskan bahwa variabel Citra Merek $\left(\mathrm{X}_{3}\right)$ memberikan dampak yang cukup besar dan signifikan terhadap keputusan pembelian barang atau jasa yang dilakukan konsumen. Hasil penelitian ini menjelaskan bahwa citra merek dapat memberikan pengaruh positif yang signifikan terhadap keputusan pembelian oleh konsumen. Hasil ini menjelaskan bahwa penilaian yang baik mengenai merek penyedia barang dan jasa, merupakan salah satu faktor yang dapat mempengaruhi terbentuknya keputusan pembelian. Hal ini disebabkan karena konsumen akan selalu mencari tahu di mana lokasi perusahaan yang memberikan satu spesifikasi yang sesuai dengan yang diharapkan oleh konsumen.

Citra merek adalah anggapan tentang merek yang direfleksikan konsumen yang berpegang pada ingatan konsumen. Citra merek juga dapat diartikan dengan cara orang berpikir tentang sebuah merek secara abstrak dalam pemikiran mereka, sekalipun pada saat 
mereka memikirkannya, mereka tidak berhadapan langsung dengan produk. Citra merek yang kuat dapat memberikan keunggulan utama bagi suatu perusahaan salah satunya akan menciptakan suatu keunggulan bersaing. Barang atau jasa yang memilki citra merek yang baik cenderung akan lebih mudah diterima oleh konsumen. Citra terhadap barang atau jasa berhubungan dengan sikap yang berupa keyakinan dan preferensi terhadap barang atau jasa.

Konsumen dengan citra positif terhadap barang atau jasa, lebih memungkinkan untuk melakukan pembelian. Oleh karena itu kegunaan utama dari iklan di antaranya adalah untuk membangun citra positif terhadap barang atau jasa. Manfaat lain dari citra produk yang positif, yaitu dengan mengembangkan barang atau jasa dan memanfaatkan citra positif yang telah terbentuk terhadap barang atau jasa yang lama. Semakin baik citra suatu merek, semakin tinggi keputusan konsumen untuk melakukan pembelian.

Perusahaan pasti memiliki nilai-nilai atau karakteristik unik yang ingin dijaga. citra merek bersumber dari pengalaman atau upaya komunikasi, sehingga penilaian maupun pengembangannya terjadi pada salah satu atau kedua hal tersebut. Upaya perusahaan sebagai sumber informasi dan terbentuknya citra merek sebagai sumber informasi dan terbentuknya citra merek memerlukan dorongan yang kuat dan informan yang lengkap dimaksudkan sebagai informasi yang dapat menjawab kebutuhan obyek sasaran. Pemahaman yang berasal dari suatu informasi yang tidak lengkap menghasilkan citra yang tidak sempurna.

Dalam keputusan pemilihan, konsumen benar-benar memilih barang atau jasa yang dianggap sesuai dengan kebutuhan dan keinginannya, di mana pada suatu brand barang atau jasa tergantung image yang melekat. Dengan begitu, perusahaan harus mampu memberikan yang terbaik dan sesuai dengan kebutuhan dan keinginan konsumen. Untuk itu perusahaan harus membangun image yang lebih menonjol daripada pesaing, dengan membuat konsumen menjadi loyal dalam menggunakan barang atau jasa tersebut secara berkala atau setidaknya konsumen puas. Dengan begitu dapat mempertahankan pangsa pasar akan membangun image positif pada konsumen. 


\section{KESIMPULAN DAN SARAN}

\section{Kesimpulan}

Berdasarkan hasil pembahasan pada

Bab sebelumnya, maka dapat disimpulkan beberapa, di antaranya adalah sebagai berikut:

1. Harga, Word of Mouth, dan Citra Merek secara simultan berpengaruh positif dan signifikan terhadap Keputusan Pembelian pada Even Organizer UN Production.

2. Harga berpengaruh negatif dan tidak signifikan terhadap Keputusan Pembelian pada Even Organizer UN Production.

3. Word of Mouth dan Citra Merek secara parsial berpengaruh positif dan signifikan terhadap Keputusan Pembelian pada Even Organizer UN Production.

\section{Saran}

Berdasarkan kesimpulan di atas, maka ada beberapa saran yang mungkin berguna di dalam meningkatkan Keputusan Pembelian pada Even Organizer UN Production, yaitu:

1) Upaya yang dapat dilakukan oleh $\mathrm{UN}$ Production di dalam meningkatkan keputusan pembelian jasa Even Organizer yang dilakukan oleh konsumen-konsumennya, antara lain: (a) Melakukan kegiatan word to mouth dengan membangun komunitas di media sosial, seperti Facebook, Linked, WhatsApp, Lines, Instagram, dan lain sebagainya;

Memperkenalkan merek dagang (citra merek) kepada khalayak ramai, seperti memasang iklan di internet, pamflet, billboard, atau publikasi ke perusahaan atau instansi yang membutuhkan jasa Event Organizer; (c) Memasang iklan di media internet, seperti OLX, Lazada, Bli-bli, atau yang lainnya, sekaligus memberikan pesan dan informasi yang detail, terutama tentang manfaat dan fasilitas jasa Event Organizer yang ditawarkannya; (d) Menawarkan jasa Event Organizer yang bervariasi dan disesuaikan dengan kebutuhan konsumen, misalnya menawarkan kualitas yang berjenjang, seperti standar, premium, VIP, atau VVIP, sehingga konsumen dapat memilih sesuai dengan kebutuhannya

2) Upaya yang dapat dilakukan oleh UN Production di dalam menetapkan harga jasa Even Organizer yang ditawarkannya, antara lain: 
Membuat jenjang kualitas jasa yang ditawarkan, misalnya: kualitas standar, premium, VIP, atau VVIP, sehingga konsumen merasa ada perbedaan harga kualitas jasa Event Organizer yang ditawarkan; (b) Menetapkan harga dengan melihat kemampuan konsumen, dengan cara melakukan tawar-menawar harga kepada konsumen dan memberikan potongan harga kepada konsumen tersebut, karena tidak semua konsumen memiliki kemampuan yang memadai, namun mereka membutuhkan jasa Event Organizer; (c) Jangan membebankan biaya transportasi kepada konsumen, namun dimasukkan ke dalam harga jasa Event Organizer, sehingga konsumen tidak merasa membayar biaya transportasi sebagai biaya tambahan; (d) Menangkap peluang trend yang sedang booming, misalnya trend yang sedang booming, yaitu acara reunian, serta memberikan potongan harga pada trend acara yang sedang booming tersebut..

3) Upaya yang dapat dilakukan oleh UN Production di dalam memperbaiki metode Word of Mouth pada jasa Even Organizer yang ditawarkannya, antara lain, sebagai berikut: Meningkatkan kualitas jasa Event Organizer yang ditawarkannya, sehingga tidak mengecewakan konsumen dalam menggunakan jasa Event Organizer yang ditawarkannya; (b) Meningkatkan pelayanan jasa Event Organizer yang ditawarkannya, sehingga menarik minat konsumen untuk jasa Event Organizer yang ditawarkannya; (c) Merencanaan dan memperthitungkan jasa Event Organizer secara matang, sehingga tidak mengecewakan dan tidak menimbulkan kesan dan persepsi buruk konsumen terhadap jasa Event Organizer yang ditawarkannya; (d) Memaparkan informasi atau pesan di dalam iklan sejelas, seteliti dan serinci mungkin, sehingga konsumen mendapatkan informasi yang lengkap atas jasa Event Organizer yang ditawarkannya.

4) Upaya yang dapat dilakukan oleh UN Production di dalam memperbaiki Citra Merek pada jasa Even Organizer 
yang ditawarkannya, antara lain: (a)

Memasang iklan yang berbayar, seperti iklan di Google, Yahoo, atau E-

Commerce, sehingga terkesan iklannya eksklusif dan akan ditayangkan setiap saat; (b) Memanfaatkan media sosail sebagai media publisitas, guna berkomunikasi dan menginformasikan jasa Event Organizer yang ditawarkan; (c) Memanfaatkan media sosail sebagai media publisitas, guna membangun persepsi positif konsumen terhadap jasa Event Organizer yang ditawarkan; (d) Menata ulang penampilan fisik kantornya semenarik mungkin, misalnya mengganti warna cat ruangan, mengganti meja kursi ruang tamu, menata ulang tata letak perlengkapan kantor, mengganti perlengkapan kantor dengan yang baru, menambah titik lampu, memasang AC atau menambah ventilasi, sehingga dapat menarik minat konsumen untuk membeli jasa Event Organizer yang ditawarkan UN Production. 
Pengaruh Harga, Word of Mouth dan.... (Nourma W, Zakaria W \& Ahmad Widad)

\section{DAFTAR PUSTAKA}

Basu Swastha, 2012. Manajemen Pemasaran, Analisa Perilaku Konsumen. Edisi Kesebelas. Penerbit Liberty. Yogyakarta.

Beatrix, S., 2013, I Love To Organize: Panduan Praktis Mengelola Event, PT. Gramedia Pustaka Utama. Jakarta.

Christoper, Edin S. Djatikusuma, dan Idham Cholid, 2015, Zen Magic Organizer, Jurnal EMBA, Volume1, Nomor 3, Juni 2017, ISSN 2303-1174

Desi Maya Kristin dan Yuliana Lisanti, 2014, Wedding Organizer Order Management, ComTech, Volume 5 Nomor 2 Desember 2014, pp. 839-850, Information Systems Department, School of Information Systems, Binus University

Duwi Priyatno, 2010. Paham Analisa Statistik Data dengan SPSS. Cetakan Pertama. Yogyakarta: Penerbit: PT. Buku Seru.

Dyah Ayu Kusumawardani dan Augusty Tae Ferdinand, 2014, Studi Mengenai Keputusan Pembelian Jasa Wedding and Event Organizer (Studi kasus di Mahkota Wedding and Event organizer Semarang), Jurnal Sains, Teknologi dan Industri, Volume 11, Nomor 2, Juni 2014, pp. 175 - 179, ISSN 1693-2390 (print), ISSN 2407-0939 (online)

Effendy, Onong Uchjana, 2012, Hubungan Masyarakat. Bandung: PT. Remaja Rosdakarya Offset.

Fandy Tjiptono, 2013. Strategi Pemasaran. Edisi Ketujuh. Penerbit CV. Andi Offset. Yogyakarta.

Ferdinand, 2012, Perilaku Konsumen, Analisis Model Keputusan, Penerbit Atma Jaya, Yogyakarta.

Fernando Is Suhendra dan Ike Juanita Tri Wardhani, 2014, Manajemen Event Organizer Pernikahan Tradisional Lintaswarna, Prosiding Penelitian Sivitas Akademika Unisba 
Journal of Management Vol. 16, No. 1, 2019:43-70

(Sosial dan Humaniora), ISSN: 2460-6537, Bidang Kajian Manajemen Komunikasi, Fakultas Ilmu Komunikasi, Universitas Islam Bandung

Frank Frank, 2013, Public Relations, Edisi Kelimabelas, Jakarta: Erlangga.

Geraldy Lie dan Rudy S.Wenas, 2017, Pengaruh Bauran, Promosi dan Persepsi Harga terhadap Keputusan Pembelian pada Sparkle The Event Organizer Manado, Jurnal EMBA, Volume 5, Nomor 3, September 2017, ISSN.2303-1174, pp. 3694-3703.

Hasan, Ali. 2013. Marketing dari Mulut ke Mulut. Yogyakarta: PT. Media Pressindo.

Hendriani, L. 2014. The Power of Event Marketing. Majalah MIX Nomor 10/III. Edisi 30, Oktober-15 November

Husein Umar, 2013. Riset Pemasaran. Penerbit PT. Gramedia Pustaka Utama. Jakarta.

I Gede Wahma Diatmika Giri dan I Made Jatra (2014), Pengaruh Iklan dan Citra Merek terhadap Keputusan Pembelian Mobil Jenis MPV Merek Toyota di Kota Denpasar, Jurnal Strategic, Volume 9, Nomor 17, Februari 2014

Keller, K.L. 2013. Manajemen Pemasaran. Alih Bahasa : Benyamin Molan. Edisi 12. Jilid 1. Penerbit Indeks Kelompok Gramedia. Jakarta.

Kementerian Perindustrian, http://www.kemenperin.go.id, diakses pada tanggal 6 Maret 2017.

Lupiyoadi, 2011, Riset Pemasaran, Edisi Pertama, Penerbit BPFE UGM, Yogyakarta.

Noer Rafikah, 2015, Analisis Pengaruh Penggunaan Jasa Event Organizer dan Sales Promotion Girl terhadap Keputusan Pembelian Rokok Apache di Kecamatan Tuban, Jurnal Administrasi Bisnis (JAB), Volume 29, Nomor1, Desember 2015, e-mail: abridwan@yahoo.co.id, website: http://www.administrasibisnis.ub.ac.id.

Philip Kotler, 2012. Manajemen Pemasaran: Analisis Perencanaan, Implementasi, dan Pengendalian. Edisi ke 11, Jilid 1, PT Indeks Kelompok Gramedia, Jakarta.

Rheland Kasali, 2013, Manajemen Public Relations. Jakarta: Penerbit PT.Grafiti. 
Pengaruh Harga, Word of Mouth dan.... (Nourma W, Zakaria W \& Ahmad Widad)

Ruslan Rosady, 2014, Manajemen Public Relation dan Media Komunikasi, Edisi Revisi, Jakarta: RT. Raja Grafindo Persada.

Saladin. 2014. Manajemen Periklanan Konsep dan Aplikasinya di Indonesia. Jakarta: Penerbit PT. Pustaka Utama Grafiti.

Santo Medy Wibisono, 2016, Strategi Komunikasi Event Organizer Movem dalam Memperkenalkan Merek Lokal melalui Penyelenggaraan Event Samarinda Street Fest di Kota Samarinda, eJournal Ilmu Komunikasi, Volume 4, Nomor 3, 2016, pp. 222236, ISSN 2502-597X,

Schiffman, Leon G. dan Kanuk, Lesli Laizer. 2012. Perilaku Konsumen. Alih Bahasa: Zoelkifli Kasip. Jakarta. PT Indeks.

Sekaran, 2011, Metodologi Penelitian untuk Bisnis Edisi ke 10. Jakarta: Salemba Empat Sernovitz, 2012, Word of Mouth Marketing. Jakarta: PT. Gramedia Pustaka Utama.

Silverman, George. 2014. The Secret of Word of Mouth Marketing: How To Trigger Exponential Sales Through Run Away Word of Mouth. USA: AMACOM.

Soemirat, Sholeh dan Ardianto, Elfinaro, 2013, Dasar-dasar Public Relation, Cetakan ke-1,. Bandung: PT. Remaja Rosdakarya Offset.

Sugiyono. 2011. Metodologi Penelitian Bisnis, Penerbit CV.Alfabeta. Bandung.

Sumardy, M. Silviana, 2011, The Power of Word of Mouth Marketing. Jakarta: Gramedia Pustaka Utama.

Sumarwan, U. 2012. Perilaku Konsumen, Teori dan Penerapannya. PT. Gramedia Pustaka Utama. Jakarta.

Suryadi, D. 2012. Promosi Efektif Menggugah Minat \& Loyalitas Pelanggan. Penerbit: Tugu Publisher, Yogyakarta

Suseno, KRMT. I. K. 2013, Cara Pintar Jadi Event Organizer, Penerbit: Galang Press. Yogyakarta 
Journal of Management
and Business Review

Walker, L. 2013. Manajemen Pemasaran. Edisi Keduabelas. Penerbit Erlangga. Jakarta.

William J. Stanton, 2011, Prinsip Pemasaran, Edisi ke 7, Jilid 1, Penerbit Erlangga, Jakarta. 